\title{
Simulation of a biogas cleaning process using different amines
}

\author{
Simulación de un proceso de purificación de biogás utilizando \\ diferentes soluciones de aminas \\ Simulação de um processo de purificação de biogás utilizando \\ diferentes soluções de aminas
}

Fecha de recepción: 5 de julio de 2017

Fecha de aprobación: 21 de octubre de 2017

\author{
Guillermo Sepúlveda* \\ Luis Eduardo Jaimes \\ Leonardo Pacheco ${ }^{\text {**t }}$ \\ Carlos Alirio Díaz
}

\section{Abstract}

The use of biogas generated in landfills has gained importance in developing countries like Colombia. Taking into account that this biogas presents poor combustion properties that make interchangeability with other combustible gases difficult, the elimination of gases and vapors, such as $\mathrm{CO}_{2}$ and $\mathrm{H}_{2} \mathrm{O}$, through a cleaning process, in which the biogas is converted to biomethane, improves the biogas properties as a fuel gas for general use. In this work, we simulated the generation of biogas at El Carrasco sanitary landfill in Bucaramanga, using the US EPA (United States Environmental Protection Agency) landfill gas emissions model. Additionally, we simulated the biogas cleaning process to extract the remaining moisture using the ProMax software; for this, we used three different amines (MDEA, MEA, and DEA), followed by a glycol dehydration process. The results showed that the amine MEA produced the largest increase in the concentration of $\mathrm{CH}_{4}(90.37 \%)$ for the biogas generated in the landfill. Furthermore, dehydration with glycol was an efficient process to obtain a gas with a high percentage of methane $(91.47 \%)$ and low water presence $(1.27 \%)$; this would allow the use of biomethane in conventional industrial combustion processes and power generation.

Keywords: amine; deacidification; biogas cleaning; simulation.

\section{Resumen}

La utilización del biogás producido en vertederos de basura ha ganado importancia en países en vía de desarrollo, como Colombia. Teniendo en cuenta que este biogás tiene propiedades pobres de combustión que dificultan el intercambio con otros combustibles, la eliminación de gases y vapores, como el $\mathrm{CO}_{2}$ y el $\mathrm{H}_{2} \mathrm{O}$, por medio de procesos de purificación en los que el biogás es convertido a biometano, mejora las propiedades del biogás como combustible para uso general. En este trabajo se simuló la producción de biogás en el vertedero de basura El

\footnotetext{
* Universidad Autónoma de Bucaramanga (Bucaramanga-Santander, Colombia). gsepulveda169@unab.edu.co.

** M.Sc. Universidad Autónoma de Bucaramanga (Bucaramanga-Santander, Colombia). 1jaimes9@unab.edu.co.

*** Ph. D. Universidad Autónoma de Bucaramanga (Bucaramanga-Santander, Colombia). lpacheco560@unab.edu.co.

**** M. Sc. Universidad Autónoma de Bucaramanga (Bucaramanga-Santander, Colombia). cdiaz23@unab.edu.co.
} 
Carrasco (Bucaramanga), usando el modelo de emisiones de gases en vertederos de la US EPA (United States Environmental Protection Agency). Adicionalmente, se simuló el proceso de purificación del biogás utilizando el software ProMax; el objetivo de este proceso es extraer la humedad del biogás, para lo cual se utilizaron tres aminas diferentes (MDEA, MEA y DEA) y un proceso posterior de deshidratación con glicol. Los resultados mostraron que la purificación con amina MEA logró producir el mayor incremento en la concentración de $\mathrm{CH}_{4}(90.37 \%)$ en el biogás generado en el vertedero. Además, la deshidratación con glicol fue un proceso eficiente para obtener gas con un alto porcentaje de metano $(91.47 \%)$ y un bajo porcentaje de agua $(1.27 \%)$; estos resultados sugieren que el biometano se podría usar en procesos industriales convencionales y en generación de energía.

Palabras clave: amina; desacidificación; purificación de biogás; simulación.

\section{Resumo}

A utilização do biogás produzido em depósitos de lixo tem ganhado importância em países em via de desenvolvimento, como a Colômbia. Tendo em conta que este biogás tem propriedades pobres de combustão que dificultam o intercâmbio com outros combustíveis, a eliminação de gases e vapores, como o $\mathrm{CO}_{2}$ e o $\mathrm{H}_{2} \mathrm{O}$, por meio de processos de purificação nos quais o biogás é convertido a biometano, melhora as propriedades do biogás como combustível para uso geral. Neste trabalho simulou-se a produção de biogás no depósito de lixo El Carrasco (Bucaramanga), usando o modelo de emissões de gases em depósitos da US EPA (United States Environmental Protection Agency). Adicionalmente, simulou-se o processo de purificação do biogás utilizando o software ProMax; o objetivo deste processo é extrair a humidade do biogás, para o qual utilizaram-se três aminas diferentes (MDEA, MEA e DEA) e um processo posterior de desidratação com glicol. Os resultados mostraram que a purificação com amina MEA logrou produzir o maior incremento na concentração de $\mathrm{CH}_{4}(90.37$ \%) no biogás gerado no depósito. Além disso, a desidratação com glicol foi um processo eficiente para obter gás com uma alta porcentagem de metano (91.47 \%) e uma baixa porcentagem de água (1.27 \%); estes resultados sugerem que o biometano poderia ser usado em processos industriais convencionais e em geração de energia.

Palavras chave: amina; desacidificação; purificação de biogás; simulação.

\section{Para citar este artículo:}

G. Sepúlveda, L. E. Jaimes, L. Pacheco, and C. A. Díaz, "Simulation of a biogas cleaning process using different amines," Revista Facultad de Ingeniería, vol. 27 (47), pp. 51-60, Jan. 2018. 


\section{INTRODUCTION}

The necessity of using combustion technologies to reduce our dependence on fossil fuels and the emission of greenhouse gases to mitigate climate change $[1,2]$ have encourage a continuous growth in the study of possible applications of alternative fuels, such as biogas. Biogas generated by the anaerobic decomposition of organic substances present in municipal solid waste can be a source of energy, especially in regions or countries where economic growth leads to an increase in the production of solid or organic waste from industrial and agricultural activities [3-8]. A variety of models can be used to estimate the generation of biogas with different degrees of certainty, depending on the composition of the matter disposed in the landfill $[9,10]$.

Biogas is mainly composed of methane $\left(\mathrm{CH}_{4}\right)$, carbon dioxide $\left(\mathrm{CO}_{2}\right)$, and other small amounts of oxygen, nitrogen, volatile compounds and even hydrogen sulfide, which are generally cleaned off to reduce the harmful effects on combustion systems [11]. The combustion properties of biogas, such as calorific value, flame temperature, and laminar flame speed are poor compared to conventional gaseous fuels such as natural gas or LPG [12-15]. Therefore, in order to use biogas in combustion systems, the design of the burners must be modified to avoid problems of flame instability associated with the lower rate of heat release, laminar flame speed, and change in flammability limits [16-18]. In order to improve the biogas combustion properties, it must be converted to biomethane by different treatments that reduce the $\mathrm{CO}_{2}$ content and its effects $[19,20]$, in addition to other secondary compounds such as $\mathrm{H}_{2} \mathrm{~S}[11,21,22]$. A purification process used to remove $\mathrm{CO}_{2}$ and $\mathrm{H}_{2} \mathrm{~S}$ uses aqueous solutions of amines in an absorption column; however, since this is a technology traditionally used to clean natural gas but not biogas, its application to biogas is still under study [23-25].

Generally, the purification process varies slightly depending on the gas to be treated (very acid or very sweet), and has three main processes: first, the deacidification that eliminates large percentages of $\mathrm{H}_{2} \mathrm{~S}$ and $\mathrm{CO}_{2}$; second, the sweetening process, where sulfur from the previous extraction is recovered; and third, the glycol dehydration, in which a large amount of water present in the gas is removed [11,21, 22, 2629].

\section{Methodology}

The amount of biogas generated and its composition was estimated using the model LandGEM of the US EPA [30, 31], which is widely applied for biogas produced in landfills. With this model, the estimation of biogas generated is improved by calculating the efficiency of the collection system in capturing the gas, which is known as the collection efficiency. The rate of biogas generation is estimated in a given year using the following first order exponential equation:

$$
Q_{L F G}=\sum_{i=1}^{n} k L_{0} M_{i}\left(e^{-k t}\right)
$$

Where $M$ is the mass of the waste disposed at a specific timet, $k$ is the biogas generation rate, which includes correction factors for methane, and $\mathrm{L}_{0}$ is the methane generation potential per unit of mass residue.

The generation of biogas is assumed to decay exponentially, and reaches its maximum point after a period of time, prior to the generation of methane. For each unit of waste, after six months, the model assumes that the biogas generation decreases exponentially, as the organic fraction of the waste is consumed. The year of maximum biogas generation is normally estimated as the year of landfill closure. To conduct the simulation and apply the biogas generation model, we used data from the city of Bucaramanga (Table 1). The waste composition was taken from the database that the used model has for each region (Table 2). These data were validated with documentation from the entities responsible for solid waste management in the city [32]. 
TABLE 1

INPUT DATA FOR THE US EPA LANDGEM BIOGAS GENERATION MODEL

\begin{tabular}{|c|c|}
\hline Landfill name & El Carrasco \\
\hline City & Bucaramanga \\
\hline Department & Santander \\
\hline Geographic Region & Andean \\
\hline Climate and average rainfall & 1990 \\
\hline Open year & 339085 \\
\hline Annual waste deposit in the last year (tons/year) & 2015 \\
\hline Estimation year & Moderately wet (1000-1499 mm/year) \\
\hline
\end{tabular}

TABLE 2

COMPOSITION OF SOLID WASTE IN BUCARAMANGA

\begin{tabular}{|c|c|}
\hline Category of residue & \% mass \\
\hline Food & 45.7 \\
\hline Paper and paperboard & 5.7 \\
\hline Gardening and pruning waste & 5.2 \\
\hline Wood waste & 6.4 \\
\hline Rubber, leather, bones and straw & 3.1 \\
\hline Textiles & 7.0 \\
\hline Toilet paper & 2.3 \\
\hline Other organics & 0.2 \\
\hline Diapers (20 \% organic and 80 \% inorganic) & 2.1 \\
\hline Metals & 1.0 \\
\hline Construction and demolition waste & 4.9 \\
\hline Glass and Ceramics & 1.1 \\
\hline Plastics & 11.9 \\
\hline Other organic waste & 3.5 \\
\hline TOTAL & 100.0 \\
\hline
\end{tabular}

Table 3 presents the temperature, composition and mass flow of the obtained biogas, according to the model used.

\section{TABLE 3}

COMPOSITION, TEMPERATURE AND MASS FLOW OF BIOGAS GENERATED ACCORDING TO THE MODEL USED

\begin{tabular}{|c|c|}
\hline Compound & Molar \% \\
\hline $\mathrm{CH}_{4}$ & $57.3 \%$ \\
\hline $\mathrm{CO}_{2}$ & $38.2 \%$ \\
\hline $\mathrm{N}_{2} \%$ & $4.5 \%$ \\
\hline $\mathrm{CO}$ & $0.001 \%$ \\
\hline $\mathrm{NH}_{3}$ & $0.00412 \%$ \\
\hline $\mathrm{H}_{2} \mathrm{~S}$ & $0.00413 \%$ \\
\hline Temperature & $45{ }^{\circ} \mathrm{C}$ \\
\hline Mass flow & $2039 \mathrm{~kg} / \mathrm{h}$ \\
\hline
\end{tabular}

Once the biogas generation and composition were obtained, according to the model and the input data, the cleaning processes of the biogas were simulated using the PROMAX software. The thermodynamic properties were determined using the Peng-Robinson equation of state.

Different amine deacidification processes were analyzed: Methyldiethanolamine (MDEA), Monoethanolamine (MEA), and Diethanolamine (DEA). These processes were chosen because the biogas obtained from a landfill lacks secondary or tertiary components of gaseous hydrocarbons [33], but it has high levels of carbon dioxide and may have carbon monoxide, sulfur hydrogen and ammonia. In order to obtain a "clean" gas, in which the undesired components have been removed, these three processes were simulated observing their behavior at cleaning the biogas. 
Given that the gas obtained from the cleaning processes is rich in $\mathrm{CH}_{4}$ and water, the sweet gas stream was taken to a dehydration unit with glycol to obtain a dry gas of better quality. The cleaning process starts when the biogas is introduced into the absorber tower, along with a stream of water and amine to obtain a stream of sweet gas and an acid gas mixed with the amine. This acid stream is heated in a heat exchanger up to about $100{ }^{\circ} \mathrm{C}$, and then is carried through a stripper, where the acid is separated from the amine by the injection of steam. The upper acid stream is brought to a condenser, and the lower amine stream is brought to a reheater, where it is separated from the water. After passing through the heat exchanger, the amine is brought to a recycling and a makeup to finally raise its pressure to again be brought to the absorber tower. The scheme of the simulated processes, using the three amines to obtain the sweet gas, is presented in Fig. 1. The absorber tower has a 7-stage TSWEET Kinetics model, and the stripper tower has a 10-stage TSWEET alternate stripper model. We used a Boston-Britt model to calculate enthalpy.

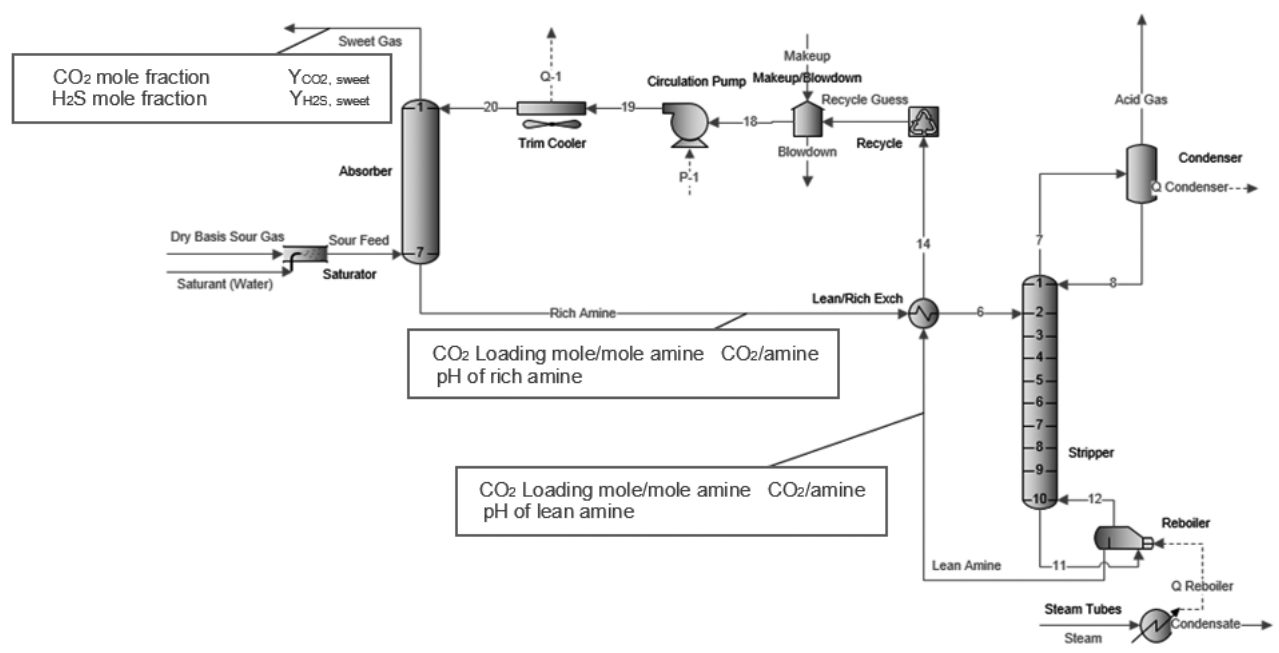

Fig. 1. Scheme of the simulated biogas sweetening process.

For each simulated process, the presence of $\mathrm{CO}_{2}$ in the sweet gas and its charge in the rich and lean amine streams (Fig. 1), which is an indicator of the ease of amine regeneration, was established as a comparison parameter. Because there was a significant percentage of water in the treated gas, a glycol dehydration process was carried out, which allowed us to obtain a dry and better-quality biogas to use as an energy source. The $\mathrm{CH}_{4}$ rich gas stream obtained was brought to the dehydration process with triethylene glycol TEG. In this process, water and glycol stream are carried out through a heat exchanger, an expansion valve, a flash separator, and finally a TEG recycling process (Fig. 2). In the contactor tower and the glycol regenerative tower, a model for the Boston-Britt enthalpy calculation was used. 


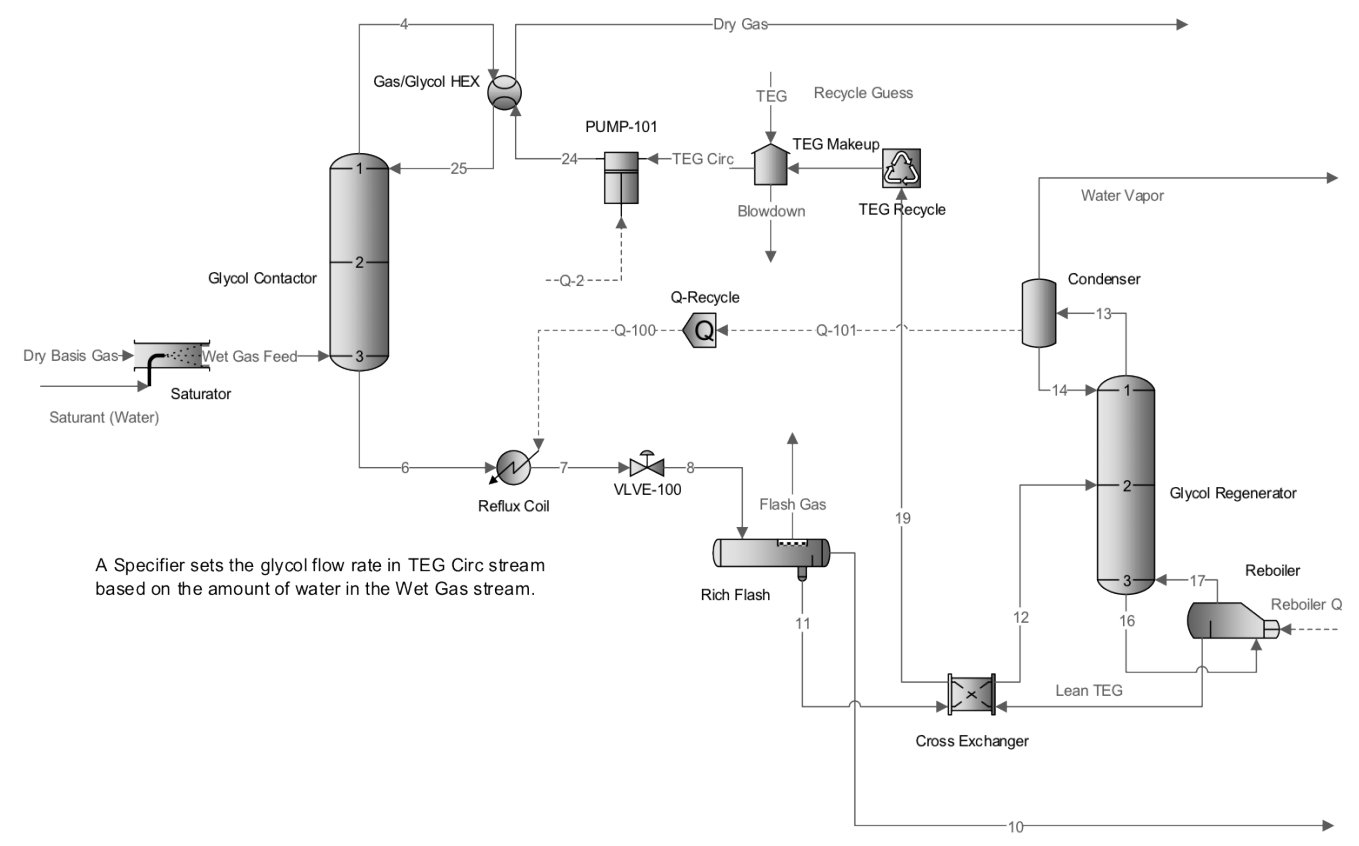

Fig. 2. Dehydration process with TEG.

\section{Results AND Discussion}

By using the three amines, similar concentrations of $\mathrm{CH}_{4}$ were observed; however, with the MEA, a near total removal of $\mathrm{CO}_{2}$ was achieved, as well as a smaller amount of $\mathrm{H}_{2} \mathrm{O}$ (Table 4).

\section{TABLE 4}

SWEET GAS COMPOSITION WITH DIFFERENT AMINES

\begin{tabular}{|c|c|c|c|}
\hline Compound & $\begin{array}{c}\text { Molar \% MDEA } \\
\text { process }\end{array}$ & Molar \% DEA process & Molar \% MEA process \\
\hline $\mathrm{CH}_{4}$ & $89.22 \%$ & $89.37 \%$ & $90.37 \%$ \\
\hline $\mathrm{CO}_{2}$ & $0.35 \%$ & $0.057 \%$ & $0.0020 \%$ \\
\hline $\mathrm{N}_{2}$ & $7.05 \%$ & $7.02 \%$ & $7.12 \%$ \\
\hline $\mathrm{CO}$ & $0.0015 \%$ & $0.0015 \%$ & $0.0015 \%$ \\
\hline $\mathrm{NH}_{3}$ & $6.014 \mathrm{e}-9 \%$ & $1.17 \mathrm{e}-17 \%$ & $9.73 \mathrm{e}-11 \%$ \\
\hline $\mathrm{H}_{2} \mathrm{~S}$ & $0 \%$ & $\approx 0 \%$ & $0 \%$ \\
\hline $\mathrm{H}_{2} \mathrm{O}$ & $3.36 \%$ & $3.54 \%$ & $2.48 \%$ \\
\hline $\mathrm{Amine}$ & $0.00059 \%$ & $2.96 \mathrm{e}-1 \%$ & $0.021 \%$ \\
\hline Molar Flow & $47.78 \mathrm{kmol} / \mathrm{h}$ & $47.93 \mathrm{kmol} / \mathrm{h}$ & $47.25 \mathrm{kmol} / \mathrm{h}$ \\
\hline
\end{tabular}

Regarding the $\mathrm{CO}_{2}$ loads, with the secondary amine DEA, a higher load was obtained on the amine exiting the absorber tower (or rich amine), and a lower load was observed on the regenerated amine stream (or lean amine), although with a lower reaction kinetics, and therefore, affecting the absorption process and its regeneration (Table 5). In the case of the tertiary amine MDEA, the $\mathrm{CO}_{2}$ charge in the amine stream exiting the absorber tower was very low due to its even lower reaction kinetics [25], and the fact that it requires a greater amount of water for its activation (Table 5). These results agree with those presented in $[23,34]$. 


\section{TABLE 5}

CO2 MOLE LOADING IN RICH AND LEAN AMINE STREAMS

\begin{tabular}{|c|c|c|c|}
\hline \multirow{2}{*}{ Parameter } & \multicolumn{3}{|c|}{ Amine } \\
\cline { 2 - 4 } & DEA & MEA & MDEA \\
\hline $\mathrm{CO}_{2}$ Loading mole/mole amine in rich amine & 0.4 & 0.2815 & 0.067 \\
\hline $\mathrm{pH}$ of rich amine & 7.84 & 8.65 & 9.326 \\
\hline $\mathrm{CO}_{2}$ Loading mole/mole amine in lean amine & 0.0065 & 0.139 & 0.0006 \\
\hline $\mathrm{pH}$ of lean amine & 9.28 & 8.17 & 9.95 \\
\hline
\end{tabular}

Taking into account the high percentage of $\mathrm{CH}_{4}$ obtained with the amine MEA, the $\mathrm{CO}_{2}$ loads in the rich and lean amine streams, and the lower presence of $\mathrm{H}_{2} \mathrm{O}$ in the sweet gas obtained, we decided to dehydrate the obtained gas with TEG. The goal was to obtain a drier landfill gas that would meet the different quality restrictions for use [11], such as a $\mathrm{CH}_{4}$ concentration greater than $90 \%$, a total concentration of gases (e.g., $\mathrm{CO}_{2}, \mathrm{~N}_{2}$ and $\mathrm{O}_{2}$ ) below $10 \%$, and a concentration of $\mathrm{H}_{2} \mathrm{O}$ below $16 \mathrm{mg} / \mathrm{m}^{3}$. These requirements may vary according to the required application of the biomethane. The MEA cleaning process produced a gas with a calorific value significantly close to the calorific value of natural gas or LPG (Table 6). Likewise, the pressure uniformly dropped along the stages of the absorber tower, while a marked temperature gradient was observed in the lower stages of the tower generated by the contact between the incoming gas stream and the MEA stream (Table 7).

TABLE 6

INLET AND OUTLET STREAM CONDITIONS IN ABSORBER TOWER

\begin{tabular}{|c|c|c|c|c|c|c|}
\hline Property & Units & $\begin{array}{c}\text { Rich } \\
\text { Amine }\end{array}$ & $\begin{array}{c}\text { Saturant } \\
\text { (Water) }\end{array}$ & $\begin{array}{c}\text { Dry Basis } \\
\text { Sour Gas }\end{array}$ & $\begin{array}{c}\text { Sweet } \\
\text { Gas }\end{array}$ & $\begin{array}{c}\text { Lean } \\
\text { Amine }\end{array}$ \\
\hline Temperature & ${ }^{\circ} \mathrm{C}$ & 83.61 & 138.37 & 45 & 50.06 & 50 \\
\hline Pressure & $\mathrm{bar}$ & 3.44 & 3.44 & 3.44 & 3.23 & 6.55 \\
\hline Mole Fraction Vapor & $\%$ & 0 & 91.96 & 100 & 100 & 0 \\
\hline Mole Fraction Light Liquid & $\%$ & 100 & 8.03 & 0 & 0 & 100 \\
\hline Molar Flow & $\mathrm{kmol} / \mathrm{h}$ & 506.20 & 2.30 & 74.78 & 47.25 & 476.36 \\
\hline Mass Flow & $\mathrm{kg} / \mathrm{h}$ & 21363.9 & 41.56 & 2039 & 801.21 & 20084.6 \\
\hline Net Ideal Gas Heating Value & $\mathrm{MJ} / \mathrm{m}^{\wedge} 3$ & - & - & 19.41 & 30.63 & - \\
\hline Net Liquid Heating Value & $\mathrm{MJ} / \mathrm{kg}$ & - & - & 16.76 & 42.74 & - \\
\hline
\end{tabular}

TABLE 7

PRESSURES AT DIFFERENT STAGES IN ABSORBER TOWER

\begin{tabular}{|c|c|c|}
\hline Stages & Temperature $^{\circ} \mathbf{C}$ & Pressure bar \\
\hline 1 & 50.0621 & 3.23821 \\
\hline 2 & 50.0517 & 3.27268 \\
\hline 3 & 50.0432 & 3.30715 \\
\hline 4 & 50.0569 & 3.34163 \\
\hline 5 & 50.38 & 3.3761 \\
\hline 6 & 54.785 & 3.41058 \\
\hline 7 & 83.6107 & 3.44505 \\
\hline
\end{tabular}

The flow conditions and composition of the treated gas obtained in the MEA (Tables 4 and 7) cleaning process were taken as the input conditions for the TEG dehydration process. After running the dehydration process, the concentrations of the wet gas components increased, whereas the concentration of the amine MEA slightly decreased, due to its solubility in the TEG stream (Table 8). 


\section{TABLe 8}

COMPOSITION OF STREAMS ON GLYCOL CONTACTOR

\begin{tabular}{|c|c|c|c|c|}
\hline Mole Fraction & Wet Gas Feed & $\mathbf{4}$ & $\mathbf{6}$ & $\mathbf{2 5}$ \\
\hline Methane & 89.1588 & 91.4973 & 0.103747 & $3.286 \mathrm{E}-09$ \\
\hline Benzene & 0 & 0 & 0 & 0 \\
\hline o-Xylene & 0 & 0 & 0 & 0 \\
\hline Ethylbenzene & 0 & 0 & 0 & 0 \\
\hline Toluene & 0 & 0 & 0 & 0 \\
\hline Water & 3.79137 & 1.27487 & 21.4947 & 6.9493 \\
\hline Triethylene Glycol & 0 & 0.0041680 & 77.7929 & 92.4161 \\
\hline $\mathrm{CO}_{2}$ & 0.0020444 & 0.0020954 & $1.847 \mathrm{E}-05$ & $3.529 \mathrm{E}-11$ \\
\hline $\mathrm{N}_{2}$ & 7.02517 & 7.21041 & 0.0022673 & $2.838 \mathrm{E}-12$ \\
\hline Monoxide & 0.0015610 & 0.0016019 & $2.059 \mathrm{E}-06$ & 0 \\
\hline MEA & 0.0210908 & 0.0095993 & 0.606393 & 0.634607 \\
\hline Ammonia & $9.607 \mathrm{E}-08$ & $9.718 \mathrm{E}-08$ & $8.513 \mathrm{E}-09$ & $1.541 \mathrm{E}-12$ \\
\hline Hydrogen Sulfide & 0 & 0 & 0 & 0 \\
\hline
\end{tabular}

The TEG dehydration process resulted in a decrease of water concentration (1.27 \%), consequently, this process produced a gas with low levels of both unwanted compounds $\left(\mathrm{CO}_{2}, \mathrm{H}_{2} \mathrm{~S}, \mathrm{NH}_{3}\right.$, and $\left.\mathrm{CO}\right)$ and water (Table 9); however, regarding the water, it was not possible to obtain a level that allows the introduction of biomethane into a natural gas distribution system.
Nevertheless, the composition obtained here could be used in combustion processes at industrial level or for power generation without the need of introducing changes in the combustion systems to avoid flame instability issues, caused by the presence of $\mathrm{CO}_{2}$, or corrosion problems caused by the $\mathrm{H}_{2} \mathrm{~S}$.

TABle 9

INLET AND OUTLET STREAM CONDITIONS IN GLYCOL CONTACTOR

\begin{tabular}{|c|c|c|c|c|c|}
\hline Property & Units & Wet Gas Feed & $\mathbf{4}$ & $\mathbf{6}$ & $\mathbf{2 5}$ \\
\hline Temperature & ${ }^{\circ} \mathrm{C}$ & 50.062 & 675.4 & 72.9 & 68.3 \\
\hline Pressure & $\mathrm{kPa}$ & 323.824 & 241.31 & 241.31 & 321.98 \\
\hline Mole Fraction Vapor & $\%$ & 100 & 100 & 0 & 0 \\
\hline Mole Fraction Light Liquid & $\%$ & 0 & 0 & 100 & 100 \\
\hline Molar Flow & $\mathrm{kmol} / \mathrm{h}$ & 47.8941 & 46.661 & 7.8051 & 6.5722 \\
\hline Mass Flow & $\mathrm{kg} / \mathrm{h}$ & 812.69 & 790.50 & 945.08 & 922.89 \\
\hline Net Ideal Gas Heating Value & $\mathrm{MJ} / \mathrm{m}^{\wedge} 3$ & 30.2228 & 31.014 & - & - \\
\hline Net Liquid Heating Value & $\mathrm{MJ} / \mathrm{kg}$ & 42.0953 & 43.335 & - & - \\
\hline
\end{tabular}

\section{Conclusions}

Four processes of biogas cleaning were simulated using the PROMAX software: deacidification with primary amines-MEA, secondary-DEA, tertiary-MDEA, and a process of dehydration with triethyleneglycol-TEG. Each deacidification process was carried out for the conditions of biogas generated in the landfill "El Carrasco" in Bucaramanga, Colombia. The results showed that the use of amines for biogas cleaning produces a significant enrichment of the landfill biogas, obtaining percentages of $\mathrm{CH}_{4}$ of up to $90 \%$ from a biogas with $57.3 \% \mathrm{CH}_{4}$. Likewise, as this enrichment is obtained, mainly at the expense of $\mathrm{CO}_{2}$ removal, these processes may be suitable for the use of renewable sources of energy with lower emission rates of greenhouse gases.

The dehydration process with TEG is necessary to remove the remaining water in the sweet gas generated by the amine regeneration processes. The sweetening processes increased the moisture content in the treated gas to $3.36 \%$ with MDEA, $3.54 \%$ with DEA and $2.48 \%$ with MEA. These percentages of water can generate instability in the gas combustion, low flame temperature, or high dew point temperature values of 
the flue gases from thier combustion. The percentage of water $(1.27 \%)$ was similar to the humidity values normally found in the combustion of gases with atmospheric air, but did not reach a level similar to those required by some natural gas distribution regulations.

This work is part of a research project on biogas cleaning for use in conventional combustion systems, and here, we presented only the results related to the increase of $\mathrm{CH}_{4}$ concentration. A parametric study of the processes in regard to the variations in the equipment design and operating conditions may alter the obtained results.

\section{ACKNowledgments}

The authors thank the Research Directorate of the Autonomous University of Bucaramanga for funding this project within the 2015-2016 biennial call for investigations.

\section{References}

[1] G. Mundaca, "How much can $\mathrm{CO}_{2}$ emissions be reduced if fossil fuel subsidies are removed?," Energy Economics, vol. 64, pp. 91-104, May. 2017. DOI: http://doi.org/10.1016/j.eneco.2017.03.014.

[2] International Energy Agency, $\mathrm{CO}_{2}$ Emissions from Fuel Combustion Highlights 2016. IEA Publications, 2016.

[3] Biogas Power (Off-grid) Programme. Available: http://mnre.gov.in/schemes/offgrid/biogas-2/.

[4] W. Ortiz, J. Terrapon-Pfaff, and C. Dienst, "Understanding the diffusion of domestic biogas technologies. Systematic conceptualization of existing evidence from developing and emerging countries," Renewable and Sustainable Energy Reviews, vol. 74, pp. 1287-1299, Jul. 2017. DOI: http://doi.org/10.1016/j.rser.2016.11.090.

[5] I. Pérez, et al., "Technical, economic and environmental assessment of household biogas digesters for rural communities," Renewable Energy, vol. 62, pp. 313-318, Feb. 2014. DOI: http://doi. org/10.1016/j.renene.2013.07.017.

[6] K. C. Surendra, D. Takara, A. G. Hashimoto, and S. K. Khanal, "Biogas as a sustainable energy source for developing countries: Opportunities and challenges," Renewable and Sustainable Energy Reviews, vol. 31, pp. 846-859, Mar. 2014. DOI: http://doi.org/10.1016/j.rser.2013.12.015.

[7] Q. Aguilar-Virgen, P. Taboada-González, and S. Ojeda-Benítez, "Analysis of the feasibility of the recovery of landfill gas: a case study of Mexico,"
J. Clean. Prod., vol. 79, pp. 53-60, Sep. 2014. DOI: http://doi.org/10.1016/j.jclepro.2014.05.025.

[8] W. Tsai, "Bioenergy from landfill gas (LFG) in Taiwan," Renewable and Sustainable Energy Reviews, vol. 11(2), pp. 331-344, Feb. 2007. DOI: http://doi.org/10.1016/j.rser.2005.01.001.

[9] J. García, et al., "Compositional analysis of excavated landfill samples and the determination of residual biogas potential of the organic fraction," Waste Manage, vol. 55, pp. 336-344, Sep. 2016. DOI: http://doi.org/10.1016/j.wasman.2016.06.003.

[10] Q. Aguilar-Virgen, et al., "Power generation with biogas from municipal solid waste: Prediction of gas generation with in situ parameters," Renewable and Sustainable Energy Reviews, vol. 30, pp. 412419, Feb. 2014. DOI: http://doi.org/10.1016/j. rser.2013.10.014.

[11] R. Kadam, and N. L. Panwar, "Recent advancement in biogas enrichment and its applications," Renewable and Sustainable Energy Reviews, vol. 73, pp. 892903, Jun. 2017. DOI: http://doi.org/10.1016/j. rser.2017.01.167.

[12] C. Díaz González, A. Amell, and J. Suárez, "Comparison of combustion properties of simulated biogas and methane," CT\&F Ciencia, Tecnología y Futuro, vol. 3(5), pp. 225-236, 2009.

[13] C. E. Lee, C. B. Oh, I. S. Jung, and J. Park, “A study on the determination of burning velocities of LFG and LFG-mixed fuels," Fuel, vol. 81(13), pp. 1679-1686, Aug. 2002. DOI: http://doi.org/10.1016/ S0016-2361(02)00049-2.

[14] Z.L. Wei, C. W.Leung, C. S. Cheung, and Z.H. Huang, "Effects of equivalence ratio, $\mathrm{H}_{2}$ and $\mathrm{CO}_{2}$ addition on the heat release characteristics of premixed laminar biogas-hydrogen flame," Int. J. Hydrogen Energy, vol. 41(15), pp. 6567-6580, Apr. 2016. DOI: http:// doi.org/10.1016/j.ijhydene.2016.01.170.

[15] L. Pizzuti, C. A. Martins, and P. T. Lacava, "Laminar burning velocity and flammability limits in biogas: A literature review," Renewable and Sustainable Energy Reviews, vol. 62, pp. 856-865, Sep. 2016. DOI: http://doi.org/10.1016/j.rser.2016.05.011.

[16] C. Lee, and C. Hwang, "An experimental study on the flame stability of LFG and LFG-mixed fuels," Fuel, vol. 86(5-6), pp. 649-655, Mar. 2007. DOI: http://doi.org/10.1016/j.fuel.2006.08.033.

[17] C. A. Díaz González, A. Amell Arrieta, and L. F. Cardona, "Estudio experimental de la estabilidad de llama de biogás en un sistema de premezcla," Energética, 39, 2008.

[18] L. Pizzuti, et al., "Laminar burning velocity and flammability limits in biogas: A state of the art," in 10th Int. Conf. on Heat Transfer, Fluid Mechanics and Thermodynamics, 2014.

[19] H. Nonaka, and F. M. Pereira, "Experimental and numerical study of $\mathrm{CO}_{2}$ content effects on the laminar burning velocity of biogas," Fuel, vol. 182, pp. 
382-390, Oct. 2016. DOI: http://doi.org/10.1016/j. fuel.2016.05.098.

[20] N. Hamidi, "Carbon dioxide effects on the flammability characteristics of biogas," Applied Mechanics and Materials, vol. 493, pp. 129-133, Jan. 2014. DOI: http://doi.org/10.4028/www.scientific. net/AMM.493.129.

[21] K. Biernat, W. Gis, and I. Samson-Bręk, "Review of technology for cleaning biogas to natural gas quality," Combustion Engines, vol. 148, pp. 33-39, 2012.

[22] M. J. Khalil, K. Sharma, and R. Gupta, "Strategic technologies for biogas purification," in National Conference on Synergetic Trends in Engineering and Technology (STET-2014), 2014.

[23] B. Morero, and E. A. Campanella, "Simulación del Proceso de Absorción Química con Soluciones de Aminas para la Purificación Biogás," Información Tecnológica, vol. 24(1), pp. 25-32, 2013. DOI: http:// doi.org/10.4067/S0718-07642013000100004.

[24] N. Abatzoglou, and S. Boivin, "A review of biogas purification processes," Biofuels, Bioproducts and Biorefining, vol. 3(1), pp. 42-71, Jan. 2009. DOI: http://doi.org/10.1002/bbb.117.

[25] P. L. Fosbøl, et al., "Design and simulation of rate-based $\mathrm{CO} 2$ capture processes using carbonic anhydrase (CA) applied to biogas," in 13th International Conference on Greenhouse Gas Control Technologies (GHGT-13), 2017.

[26] R. Ochieng et al., "Simulation of the Benfield HiPure process of natural gas sweetening for LNG production and evaluation of alternatives," in Proceedings of Sour Oil and Gas Advanced Technology, 2012.

[27] V. N. Hernández, M. W. Hlavinka, and J. Bullin, "Design glycol units for maximum efficiency", in Proceedings of the Annual Convention-Gas Processors Association, 1992.

[28] K. W. Mattsson-Bose, and L. G. Lyddon, "Using a process simulator to improve sulphur recovery," Sulphur-London-, pp. 37-42, 1997.

[29] S. Rasi, Biogas Composition and Upgrading to Biomethane. Jyväskyla: University of Jyväskyla, 2009.

[30] A. Alexander, C. Burklin, and A. Singleton, "Landfill Gas Emissions Model (LandGEM) Version 3.02," US Environmental Protection Agency, Eastern Research Group, 2005.

[31] H. Kamalan, M. Sabour, and N. Shariatmadari, "A review on available landfill gas models," Journal of Environmental Science and Technology, vol. 4(2), pp. 79-92, Feb. 2011. DOI: http://doi.org/10.3923/ jest.2011.79.92.

[32] Alcaldía de Bucaramanga, Plan de Gestión Integral de Residuos Sólidos Pgirs. Bucaramanga: 2015.

[33] E. Erdmann, et al., "Endulzamiento de gas natural con aminas. Simulación del proceso y análisis de sensibilidad paramétrico," Avances en Ciencias e Ingeniería, vol. 3(4), 2012.

[34] F. R. Abdeen, et al., "A review of chemical absorption of carbon dioxide for biogas upgrading," Chin. J. Chem. Eng., vol. 24(6), pp. 693-702, Jun. 2016. DOI: http://doi.org/10.1016/j.cjche.2016.05.006. 